\title{
SELF-EFFICACY BELIEFS AND ATTITUDES OF EFL TEACHERS TOWARDS WEB 2.0 TOOLS*
}

\author{
Eyyup YAPRAK ${ }^{1}$, Gülden TÜM ${ }^{2}$
}

\begin{tabular}{l} 
Makale Bilgisi \\
\hline Research Article \\
DOI: $10.35379 /$ cusosbil.1031764 \\
\hline Article History: \\
Received 08.12.2021 \\
Revised 14.12 .2021 \\
Accepted 16.12 .2021 \\
\hline Keywords: \\
Web 2.0 Tools, \\
Self-efficacy Beliefs, \\
EFL Teachers, \\
Attitudes, \\
ELT.
\end{tabular}

\section{İNGILİZCE ÖĞRETMENLERİNİN WEB 2.0 ARAÇLARINA YÖNELİK} ÖZYETERLIK İNANÇ VE TUTUMLARI

\begin{tabular}{l} 
Article Info \\
\hline Araştırma Makalesi \\
DOI: $10.35379 /$ cusosbil.1031764 \\
\hline \multicolumn{2}{l}{ Makale } & Geçmişi: \\
Geliş $\quad 08.12 .2021$ \\
Düzeltme $\quad 14.12 .2021$ \\
Kabul $\quad 16.12 .2021$ \\
\hline Anahtar Kelimeler: \\
Web 2.0 Araçları, \\
Öz-yeterlik İnançları, \\
İngilizce Öğretmenleri, \\
Tutumlar, \\
İngilizce Öğretimi.
\end{tabular}

\footnotetext{
* Bu çalışma Çukurova Üniversitesi Sosyal Bilimler Enstitüsü İngiliz Dili Eğitimi Anabilim dalında Doç. Dr. Gülden TÜM danışmanlığında Eyyup YAPRAK tarafindan yazılan “An Investıgatıon Into Efl Teachers' Self-Efficacy Beliefs, Frequency of Use and Attitudes Towards Web 2.0 Tools" başlıklı yüksek lisans tez çalışmasından üretilmiştir. Ayrıca bu çalışma 4. Uluslararası Sinırsız Eğitim ve Araştırma Sempozyumu'nda (USEAS 2020) bildiri olarak sunulmuşur.

${ }_{1}^{1}$ Yükssek Lisans Öğrencisi, Çukurova Üniversitesi, Eğt. Fak, İngilizce Bölümü, eyyupyaprak@ gmail.com, ORCID: 0000-0002-9456-2658.

${ }^{2}$ Doç.Dr., Cukurova Üniversitesi, Eğt. Fak, Yabancı Diller, guldentum@gmail.com, ORCID: 0000-0001-7790-0857.

Alıntılamak için/ Cite as: Yaprak, E. \& Tüm, G. (2021), Self-Efficacy Beliefs and Attitudes of EFL Teachers towards Web 2.0 Tools, Çukurova Üniversitesi Sosyal Bilimler Enstitüsü Dergisi, 30 (3), 235-250.
} 
Çukurova Üniversitesi Sosyal Bilimler Enstitüsü Dergisi, Cilt 30, Sayı 3, 2021, Sayfa 235-250

\section{INTRODUCTION}

Currently, the constant developments in the fields of science and technology call for the change in the use of technological equipment in educational sciences as in all fields. In today's educational institutions, such technologies used in the form of interactive smart board, tablet, and portable computer have substituted for the traditional teaching materials. The educational institutions of the countries carry out different projects in order to ensure that teachers and students can benefit from these technologies effectively, in addition to creating qualified learning environments appropriate to the needs of the current century. Accordingly, the Ministry of National Education (MoNE) initiated the FATIH (Movement of Enhancing Opportunities and Improving Technology) project in 2010 in Turkey. With this project, it is aimed to increase the quality of education by ensuring the effective use of Information and Communication Technologies (ICT) in the courses by ensuring equal opportunities in education and improving the technological infrastructure of schools (MoNE, 2018). Thus, technology becomes available in the most of the Turkish public schools, teachers have many opportunities to create effective learning environments on the digital platforms and to prepare supplementary teaching materials. Among these, Web 2.0 tools, which offer different kinds of services to the user, are of significant. Web 2.0 applications provide users with various kinds of web-based applications (O'Reilly, 2005) and enable usergenerated content by offering various opportunities for individuals to communicate and share the content (Thompson, 2007). Teachers who incorporate Web 2.0 tools might "attract students to school work, meet individual learning needs, develop their critical thinking skills, provide an alternative learning environment, expand learning outside schools, and prepare students for lifelong learning" (Lemke et al., 2009, p. 7). As students are encouraged to be active participants in the classroom and contribute to the content, Web 2.0 tools provide them with the opportunity to create, manipulate and control the content, and socialize by means of it (Horzum, 2007). Moreover, the development of Web 2.0 tools can be considered a technological innovation that supports the change in the education system and can be utilized easily. Students capable of using Web 2.0 tools are not merely individuals who consume information given in classrooms; they become active actors that produce new information, manipulate it, and question the source of the information as well. To cope with those students, teachers are urgently expected to learn how to operate Web 2.0 tools effectively in their instructions. However, at this point, the most serious problem ahead of today's teachers is the Generation Z, whose dates range from the year 1995 (Pacis et al., 2012) to the year after 2000 (Twenge et al., 2010). This generation, intertwined with technology, is also called "Net generation" (Oblinger \& Oblinger, 2005; Schulmeister, 2008) and "Digital natives" (Prensky, 2001) since they were born in an age that is completely dominated by technology. Generation $\mathrm{Z}$ is technology enthusiast, conform to informality, learn quickly and embrace diversity (Twenge et al., 2010). The use of Web 2.0 tools in teaching and learning processes of the $\mathrm{Z}$ generation is no longer a necessity, but an obligation. Additionally, Web pedagogy content knowledge includes self-efficacy beliefs and attitudes of teachers towards the use of the web environment for pedagogical purposes (Horzum, 2011). Bandura (1995) defines self-efficacy as an individual's belief in himself in achieving the set goals or in performing a task. While self-efficacy affects the selection of activities to be performed by an individual, the expectation of success determines how much effort is to be made and how much time is to be spent to deal with the difficulties.

\section{LITERATURE REVIEW}

\section{Web 2.0 Self-efficacy Beliefs of Teachers}

Web 2.0 self-efficacy beliefs are crucial for teachers and their use of technology in their classroom is a powerful determinant of how effectively they will actually utilize technology (Abbitt, 2011). That is, Web 2.0 applications and services enable users to share content without facing technical barriers, while at the same time making use of the Internet's potential for social interaction and collaboration, rather than using the internet merely as an information provider. In the Web 2.0 realm, all members of a party can contribute to create rich content (Solomon \& Schrum, 2007). Web 2.0 refers to the use of the Internet as a mediator to promote interaction among users through tools and technologies such as Blogs, Wikis, or Podcasts (Kostoula-Christina, 2016), Social Networking Sites, Image/Photo Sharing Sites, and Course Management Systems (Davies \& Merchant, 2008). Therefore, Web 2.0 tools can be called a platform where content is produced, shared, combined and transferred with the participants. Similarly, Brown (2009) argues that popularity and availability of Web 2.0 tools have enabled today's users, who used to visit only non-interactive web pages, to become individuals who share, interpret, collaborate and interact with information, actively participate and produce contents. In the same vein, Web 2.0 tools in teaching and learning support the users to work with flexible time 
Çukurova Üniversitesi Sosyal Bilimler Enstitüsü Dergisi, Cilt 30, Sayı 3, 2021, Sayfa 235-250

intervals and the users' creativity. They are user-friendly programs with very easy-to-use features as many videos and animations relevant within these programs are easily accessible. All these are deduced by social cognitive theory, dating back to the late 1800 s, and defining human behaviour as a dynamic and reciprocal relationship of personal factors, behaviours and environment (Bandura, 1977, 1986, 1989). Bandura (1986) bases his social cognitive theory on six principles including mutual decisiveness, capacity of symbolization, capacity of foresight, capacity of indirect learning, capacity of self-regulation and capacity of self-judgement wherein the self-efficacy is tremendously reflected.

\section{Technology Acceptance and Adoption Models}

The terms "innovation" and "technology" are often used as synonyms (Rogers, 1983). Many researchers engaged in studies on this subject have proposed different methods on the acceptance and adoption process of technology. The key goal of these models is to determine which internal or external factors are influenced by the intention of use, which is the main factor in the use of technology. These models are useful for understanding and evaluating the diffusion of innovation, and making sense of the acceptance of innovation by individuals as given in Table 1.

Table 1. Summary of Technology Acceptance Theories

\begin{tabular}{|c|c|c|}
\hline Model & Constructs/Determinants of behaviour & Theories/ Models \\
\hline $\begin{array}{c}\text { TAM } \\
\text { (Technology } \\
\text { acceptance model) }\end{array}$ & perceived usefulness, perceived ease of use & (Davis, 1986) \\
\hline $\begin{array}{c}\text { TAM2 } \\
\text { (Technology } \\
\text { acceptance model 2) }\end{array}$ & $\begin{array}{l}\text { perceived usefulness, subjective norm, image, job relevance, output } \\
\text { quality, result demonsrability, voluntariness, experience, perceived ease } \\
\text { of use and intention to use }\end{array}$ & $\begin{array}{l}\text { (Venkatesh \& Davis, } \\
\text { 2000) }\end{array}$ \\
\hline $\begin{array}{c}\text { TAM3 } \\
\text { (Technology } \\
\text { acceptance model 3) }\end{array}$ & $\begin{array}{l}\text { perceived usefulness, subjective norm, image, job relevance, output } \\
\text { quality, result demonsrability, voluntariness, experience, perceived } \\
\text { intention to use, computer self-efficacy, perceptions of external control, } \\
\text { computer anxiety, computer playfulness, perceived enjoyment, } \\
\text { objective usability }\end{array}$ & (Venkatest\&Bala, 2008) \\
\hline $\begin{array}{c}\text { TRA } \\
\text { (Theory of reasoned } \\
\text { action) }\end{array}$ & $\begin{array}{l}\text { attitude towards behavior, subjective norm, behavioral intention and } \\
\text { actual behavior }\end{array}$ & $\begin{array}{l}\text { (Ajzen \& Fishbein, } \\
\text { 1980; Fishbein \& Ajzen, } \\
\text { 1975) }\end{array}$ \\
\hline $\begin{array}{c}\text { TPB } \\
\text { (Theory of planned } \\
\text { behaviour) }\end{array}$ & $\begin{array}{l}\text { behavioral attitude, subjective norm, perceived behavioral control, } \\
\text { intention and behavior }\end{array}$ & (Ajzen, 1985) \\
\hline $\begin{array}{c}\text { DTPB } \\
\text { (Decomposed theory of } \\
\text { planned behaviour) }\end{array}$ & $\begin{array}{l}\text { perceived usefulness, perceived ease of use, compability, peer influence } \\
\text { and superior's influence, self-efficacy, resource facilitating conditions } \\
\text { and technology facilitating conditions }\end{array}$ & (Taylor \& Todd, 1995) \\
\hline $\begin{array}{c}\text { UTAUT } \\
\text { (Unified theory of } \\
\text { acceptance and use of } \\
\text { technology) }\end{array}$ & $\begin{array}{l}\text { performance expectancy, effort expectancy, social influence and } \\
\text { facilitating conditions }\end{array}$ & (Venkatesh et al., 2003) \\
\hline $\begin{array}{c}\text { IDT } \\
\text { (Innovation Diffusion } \\
\text { Theory) }\end{array}$ & $\begin{array}{l}\text { relative advantange, trialability, observability, compatibility, } \\
\text { complexity }\end{array}$ & (Rogers, 1983, 1995) \\
\hline $\begin{array}{c}\text { SCT } \\
\text { (Social cognitive } \\
\text { theory) }\end{array}$ & behavior, environmental factor, personal factor & (Bandura, 1986) \\
\hline
\end{tabular}

As afore-mentioned in Table 1, various models and theories have been developed by various researchers since 1975 regarding the adoption and acceptance of information technologies among people. However, there is no clear conclusion among research (Davis, 1989; Taylor \& Todd, 1995; Venkatesh, et al., 2003) that any of these models is superior to others in explaining the adoption and behavior of technology use (Ursavaş et al., 2014). This study is based on the Decomposed Theory of Planned Behavior (see Figure 01) to understand ELT teachers' intention to use Web 2.0 (Taylor \& Todd, 1995)

\section{Decomposed Theory of Planned Behaviour (DTPB)}

Decomposed Theory of Planned Behaviour (DTPB) introduced by Taylor and Todd (1995) shares the similar principles with other theories examining technology acceptance and associates behaviour with intention. Taylor 
Çukurova Üniversitesi Sosyal Bilimler Enstitüsü Dergisi, Cilt 30, Sayı 3, 2021, Sayfa 235-250

and Todd (1995) added new sub-variables (compatibility, environmental impact, self-efficacy, resourcefacilitating conditions, and technology-facilitating conditions) that determine attitude, subjective norm, and perceived behavioral control. In doing so, they aimed to explain performed behavior of an individual. Similarly, this research employs the DTBP developed by Ajjan and Hartshorne (2008).

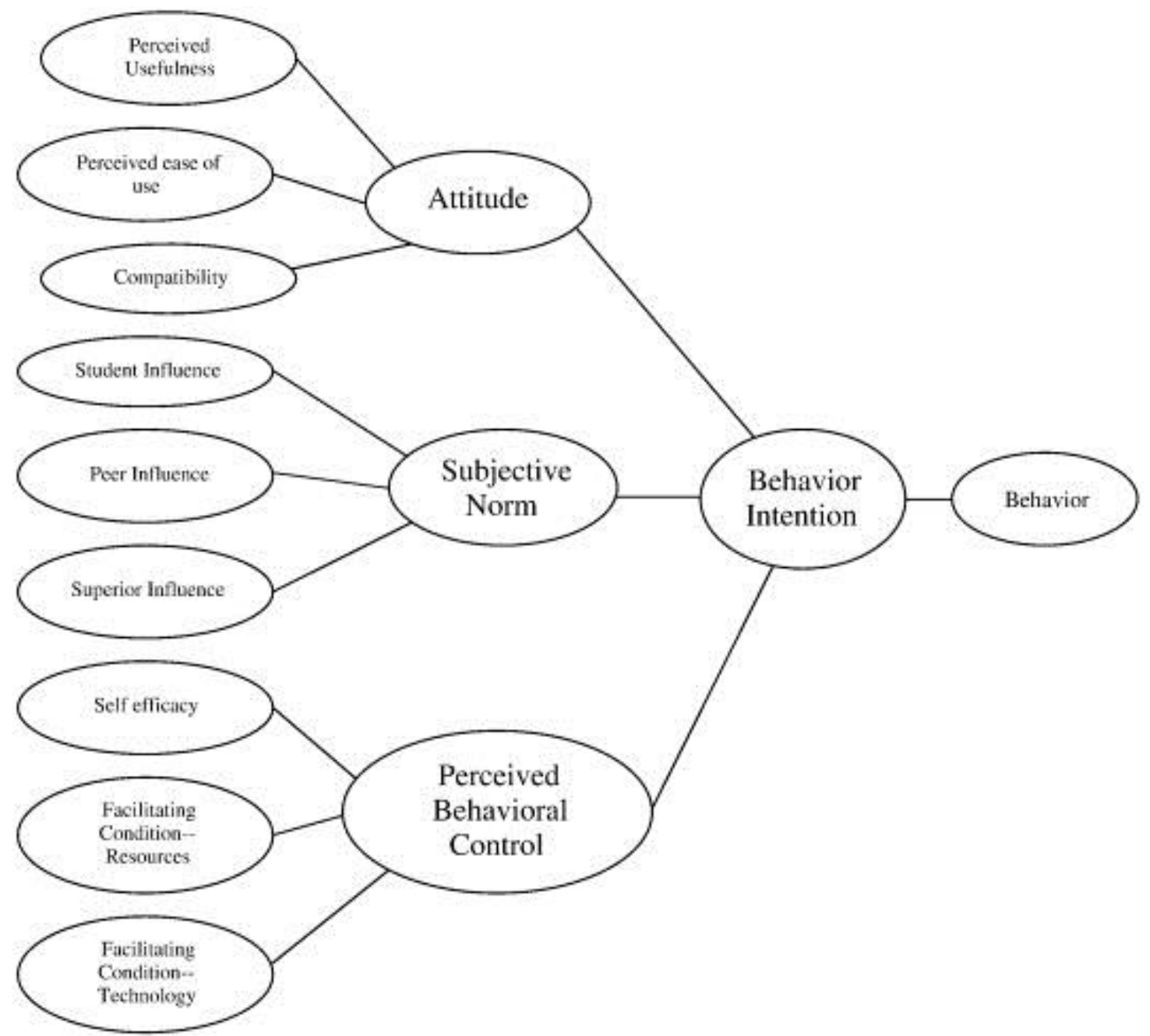

Figure 1. The Decomposed Theory of Planned Behaviour (Source: Ajjan \& Hartshorne, 2008, p.73)

As observed above, DTPB includes three main constructs (attitude, subjective norms, and behavioural control). Attitude construct consists of three sub variables related to behaviour: perceived usefulness, perceived ease of use, and compatibility. Subjective norms are divided into three sub-constructs: student, peer, and superior. The opinions of the two groups were separated in DTPB, as their opinions might differ in using a technology. Perceived behavioral control items are divided into three categories: self-confidence, facilitating condition-resources, and facilitating condition-technology.

\section{Web 2.0 Tools Attitudes of Teachers}

Ajzen and Fishbein (1980) describe the attitude as a tendency to react consistently, positively or negatively to any object presented as a result of learning. Eagly and Chaiken (1993) interpret the attitude as a psychological tendency to evaluate a certain phenomenon or object to a certain extent, positively or negatively. Teachers' attitudes towards using technology in education context can be described as a factor that affects to what extend teachers benefit and use the technology in learning-teaching process. In order to integrate Web 2.0 tools effectively into the learning environment, teachers who are most effective agents in the process of teaching must 
adopt a positive attitude towards technology. In a similar vein, research reports that teacher attitude is one of the most important factors enabling effective ICT usage in teaching and learning environment (Kreijns et al., 2013). Gabriel and Macdonald (1996) state that the negative attitudes prevailing in schools where tech-savvy students are studying may affect the attitudes of teachers. Haydn and Barton (2007) accentuate that many teachers do not use technology in the teaching process to increase learning and feel insufficient about using technology in teaching. This imposes important responsibilities on teachers for the effective use of technology in educational environments. An effective way to solve this issue is to provide teachers with trainings through which they can gain necessary knowledge, skills and positive attitudes towards technology integration. Therefore, the present study aimed to investigate the relationship between the self-efficacy beliefs and attitudes of the EFL teachers towards the Web 2.0 tools in Turkey.

\section{METHODOLOGY}

The mixed method design to get better and safer results combining both quantitative and qualitative research techniques in one study (Creswell et al., 2003) is utilized to confirm or cross-validate relationships discovered between variables (Fraenkel et al., 2012). The study, applied during the spring semester of 2018 and 2019 Academic Year in Bağlar, Yenişehir, Kayapınar, and Sur districts of Diyarbakır, Turkey, adopted two data tools: questionnaire and semi-structured interview. The respondents of the questionnaire were ( $\mathrm{n}=202 ; \mathrm{M}-88, \mathrm{~F}-114)$ EFL teachers ranging from 24 to 44 years old and coming from 183 public schools. As for semi-structured data collection, 10 EFL teachers from 10 different schools participated as the interviewees who were selected through convenience sampling of nonprobability method because of accessibility and proximity. However, since convenience sampling involves choosing those institutions flexible and easy to access, it might not represent any group separately from itself; it may not be used to generalize the sample to the larger population (Cohen et al., 2007). This weakness might produce a bias, but this can be overcome by using triangulation, in which using different methods for collecting the data within one study will enhance the reliability and validity. The present study was limited to adult EFL teachers working in public schools, Diyarbakır, south-eastern part in Turkey. In addition, the semi-structured interviews were only conducted with 10 EFL teachers who have a Bachelor of Arts (BA) or a Master of Arts (MA) in ELT. A larger number of participants would increase the reliability of the research findings.

\section{Data Collection Tools}

The questionnaire included demographic data from participants (gender, age, teaching experience, university degree, in-service training background, years of use of technology in teaching, years of service in teaching, and the level of education in teaching and the district of service). It also included Web 2.0 Tools Integration SelfEfficacy Instrument (WTISEI) developed by Pan \& Franklin (2011). The 27-item WTISEI focused on assessing the level of the EFL teachers' self-efficacy in using Web 2.0 tools in their teachings in five items accompanied by a five-point Likert scale: "strongly agree (5)", "agree (4)", "neutral (3)", “disagree (2)", and "strongly disagree (1)". WTISEI obtained a high reliability of Cronbach alpha 0.97 similar result to Pan and Franklin's (2011) study $\alpha=0.98$. The final part of the questionnaire involved the Decomposed Theory of Planned Behaviour (DTPB) model to measure attitudes (Ajjan \& Hartshorne, 2008) of the EFL teachers towards Web 2.0 tools. The 35-item DTPB instrument consisted of items using a five point Likert-scale (strongly disagree to strongly agree) to examine factors that influence EFL teachers' intentions to utilize Web 2.0 technologies in their classrooms. Items focused on areas of actual usage/behaviour, behavioural intention, attitude, ease of use, perceived usefulness, subjective norms, perceived behavioural control, peer influence, superior influence, student influence, compatibility, facilitating conditions (technology and resources), and self-efficacy. The purpose of utilizing the DTBP was to shed light on the relationship of the antecedents and better understand the agents that influence the adoption or use of new technology (Taylor \& Todd, 1995). Therefore, in this study, this model was opted for the explanation of the adoption intention and use of Web 2.0 tools by EFL teachers. The means of Cronbach alpha for the overall scales of this instrument resulted $\alpha=0.98$.

Subsequently, with the purpose of providing in-depth analysis for the quantitative data, semi-structured interviews were conducted with voluntarily selected EFL teachers regarding their self-efficacy beliefs and attitudes towards Web 2.0 tools incorporation in language teaching. The rationale behind it was to "explore in detail the experiences, motives and opinions of others and learn to see the world from the perspectives other than their own" (Rubin \& Rubin, 2012, p.3). A non-threatening atmosphere for the interviews and interviewees were provided. In an attempt to verify the validity of the instruments exploited in the study, a pilot study was 
Çukurova Üniversitesi Sosyal Bilimler Enstitüsü Dergisi, Cilt 30, Sayı 3, 2021, Sayfa 235-250

conducted with a total number of 10 EFL teachers to address the face validity of the items to determine if the instrument appears to be measuring intended (Lodico et al., 2010). Minor phrasing revisions were incorporated into the final version of the questionnaire utilized in the present study. This study utilized Cronbach's alpha to create a coefficient of internal consistency. In order to decide the internal reliability of the survey instrument, SPSS 24 Edition was used. The value of the Cronbach's alpha of the instruments, including Web 2.0 Tools Integration Instrument $(\alpha=0.80)$, Web 2.0 Tools Integration Self-Efficacy Instrument $(\alpha=0.97)$, and the Decomposed Theory of Planned Behaviour $(\alpha=98)$ model was done, respectively. To conduct a reliable factor analysis, the sample size needs to be big enough. Yet, Field (2009) states that a researcher needs at least 5 to 10 participants per item in the scale. If a factor explains lots of variance in a dataset, variables correlate highly with that factor with four or more loadings greater than 0.6 "is reliable regardless of sample size" (Field, 2009, p. 647).

To determine the construct validity of the input dataset of Web 2.0 tools Integration Self-Efficacy Instrument (WTISEI) with 27-items responded by 202 participants, a factor analysis was examined through Kaiser-MeyerOlkin $(\mathrm{KMO}=0.94)$ and Bartlett's test. The KMO value of this input dataset falls within the last category listed above. Besides, the chi-square value $(\chi 2=6344.75)$ of this dataset obtained with Bartlett's test was found to be significant $(\mathrm{df}=351, \mathrm{p}<.001)$. Both KMO and Barlett's tests corroborate the suitability of the factor analysis to dataset. After measuring the suitability of the dataset for factor analysis, VARIMAX rotation was also utilized in Principal Component Analysis to establish the sub-scales of the WTISEI.

The DTPB instrument produced results of reliability values ranging from $\alpha=0.77$ to $\alpha=0.95$, which is acceptable for exploratory research (Ajjan \& Hartshorne, 2008) and Nunnally (1978) who reports that research incorporates instruments into basic research should have reliability of .70 or better. To Ritter (2010), Cronbach's alpha is developed based on the necessity to evaluate items scored in multiple answer categories. A Cronbach test was employed for alpha reliability on each of the constructs in DTPB instrument as given in Table 2.

Table 2. Reliability Analysis of Each Construct the DTPB Model to Measure Attitudes

\begin{tabular}{|l|c|}
\hline Construct & $\boldsymbol{\alpha}$ value \\
\hline Actual usage/behaviour & 0.77 \\
\hline Behavioural intention & 0.94 \\
\hline Attitude & 0.89 \\
\hline Ease of use & 0.89 \\
\hline Perceived usefulness & 0.95 \\
\hline Subjective norms & 0.92 \\
\hline Perceived behavioural control & 0.81 \\
\hline Peer influence & 0.91 \\
\hline Superior influence & 0.93 \\
\hline Student influence & 0.92 \\
\hline Compatibility & 0.92 \\
\hline Facilitating conditions-technology/resources & 0.82 \\
\hline Self-efficacy & 0.81 \\
\hline & 0.98 \\
\hline
\end{tabular}

As indicated in Table 2., reliability ranged from 0.77 to 0.95 , all constructs proved an acceptable reliability (>.70) to measure internal consistency of this instrument.

In Exploratory Factor Analysis, the suitability of the data set collected from 202 participants was investigated. The suitability of 13-item scale items for factor analysis was examined with Kaiser-Meyer-Olkin (KMO) and Bartlett test. The KMO value calculated for sample suitability is .92 . The Chi-Square value $(\chi 2=2519.289$, SD $=78, \mathrm{p}<.001)$ which was obtained by the Bartlett test was found significant. Principal components technique and varimax rotation were used for factor analysis. Table 5 presents factor loading of items and percentage of explained variance as follows: 
Çukurova Üniversitesi Sosyal Bilimler Enstitüsü Dergisi, Cilt 30, Sayı 3, 2021, Sayfa 235-250

Table 3. Factor Loading of Items and Percentage of Explained Variance

\begin{tabular}{|c|c|c|c|c|}
\hline Factor & $\begin{array}{l}\text { Item } \\
\text { No }\end{array}$ & Statements & $\begin{array}{l}\text { Factor } \\
\text { Load }\end{array}$ & $\begin{array}{c}\text { Variance } \\
\text { Explained } \\
\% \\
\end{array}$ \\
\hline & & When using Web 2.0 Tools in teaching, I feel confident that I can... & & \\
\hline \multirow{5}{*}{$\begin{array}{l}\text { Perceived } \\
\text { Usefulness }\end{array}$} & PU1 & I feel that using Web 2.0 will help my students learn more about the subject & .84 & \multirow{5}{*}{59.82} \\
\hline & PU2 & I feel that using Web 2.0 will improve students' satisfaction with the course & .86 & \\
\hline & PU3 & I feel that using Web 2.0 will improve students' grades & .87 & \\
\hline & PU4 & I feel that using Web 2.0 will improve students' evaluation & .86 & \\
\hline & PU5 & $\begin{array}{l}\text { To help my students better learn the material, I will incorporate Web } 2.0 \\
\text { technologies in the classroom }\end{array}$ & .76 & \\
\hline \multirow{5}{*}{$\begin{array}{l}\text { Subjective } \\
\text { norms }\end{array}$} & SN1 & My peers are using Web 2.0 technologies in their classroom & .81 & \multirow{5}{*}{12.22} \\
\hline & SN2 & $\begin{array}{l}\text { My superior confirms my ability and knowledge to use Web } 2.0 \text { technologies in } \\
\text { the classroom }\end{array}$ & .84 & \\
\hline & SN3 & My peers think I will benefit from using Web 2.0 technologies in my classroom & .79 & \\
\hline & SN4 & My superior thinks it is important I use Web 2.0 technologies in my classroom & .83 & \\
\hline & SN5 & My students thinks it is important I use Web 2.0 technologies in my classroom & .72 & \\
\hline \multirow{3}{*}{$\begin{array}{l}\text { Behavioural } \\
\text { Intention }\end{array}$} & INT1 & I plan to use Web 2.0 technologies in my classroom & .89 & \multirow{3}{*}{9.94} \\
\hline & INT2 & I intend to use Web 2.0 technologies within the next semester & .85 & \\
\hline & INT3 & I will add Web 2.0 technologies to my class next semester & .86 & \\
\hline
\end{tabular}

Table 3 reveal that 13 items fall into under three sub-scales which account for the total variance of $82.0 \%$. The dimensions' sub-scales constitute the same factor as Perceived Usefulness (59.82\%), Subjective Norms (12.22\%), and Behavioural Intention (9.94\%). The following table indicates fit values for the proposed DTBP model and the extend of values obtained by the Confirmatory Factor Analysis of the Web 2.0 adoption scale.

Table 4. Fit values for the Proposed Model

\begin{tabular}{|l|l|l|l|}
\hline Values & Good Fit Values & Acceptable Fit Values & DTPB \\
\hline $\mathrm{X}^{2} / \mathrm{df}$ & $.00<\mathrm{X}^{2} / \mathrm{df} \leq 2$ & $2 \leq \mathrm{X}^{2} / \mathrm{df} \leq 3$ & 2.37 \\
\hline RMSEA & $.00<\mathrm{RMSEA} \leq .05$ & $.00 \leq \mathrm{RMSEA}<.10$ & .08 \\
\hline RMR & $.00<\mathrm{RMR} \leq .05$ & $.05 \leq \mathrm{RMR} \leq .08$ & .04 \\
\hline SRMR & $.00<\mathrm{SRMR} \leq .05$ & $.00 \leq \mathrm{SRMR} \leq .10$ & .04 \\
\hline NFI & $.95 \leq \mathrm{NFI} \leq 1.00$ & $.90 \leq \mathrm{NFI} \leq .95$ & .97 \\
\hline NNFI & $.97 \leq \mathrm{NNFI} \leq 1.00$ & $.95 \leq \mathrm{NNFI} \leq .97$ & .98 \\
\hline CFI & $.95<\mathrm{CFI}<1.00$ & $.95<\mathrm{CFI}<1.00$ & .98 \\
\hline GFI & $.95<\mathrm{GFI}<1.00$ & $.90<\mathrm{GFI}<.95$ & .90 \\
\hline
\end{tabular}

The results displayed in Table 4 reveal that the values obtained by the Confirmatory Factor Analysis of the Web 2.0 adoption scale are either good fit or acceptable. The fit index values of the model obtained in CFA tested with 3 latent variables and 13 indicator variables were examined and the Chi-Square value $(\mathrm{X} 2=147.30$. $\mathrm{n}=202, \mathrm{sd}=62, \mathrm{p}=0.00$ ) was found significant. The fit index values were found as RMSEA $=.083, \mathrm{RMR}=$ $.039, \mathrm{SRMR}=.041, \mathrm{NFI}=.97, \mathrm{NNFI}=.98 \mathrm{CFI}=.98, \mathrm{GFI}=.90$. 
Çukurova Üniversitesi Sosyal Bilimler Enstitüsü Dergisi, Cilt 30, Sayı 3, 2021, Sayfa 235-250

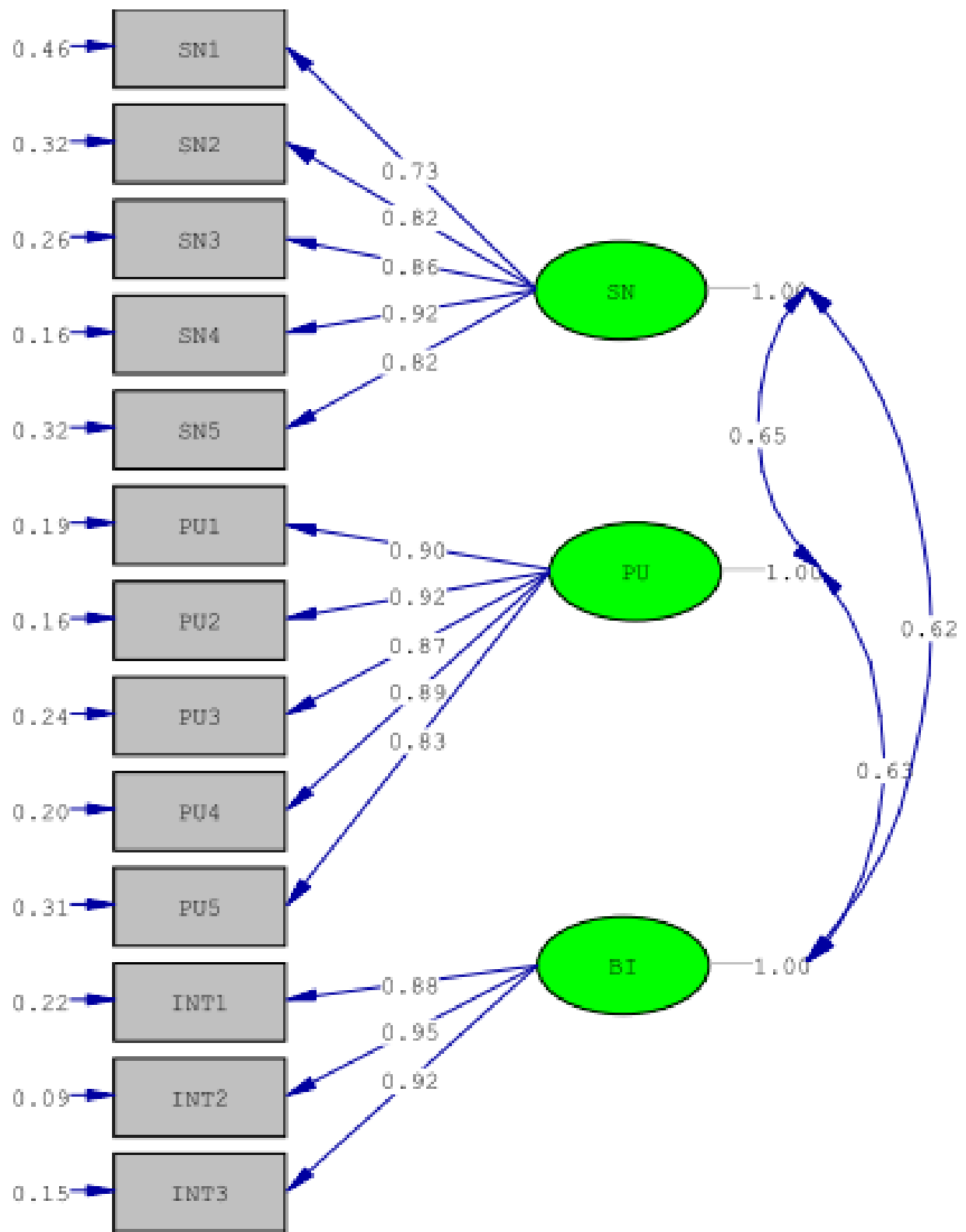

Figure 2. The three-factored latent structure founded with first order CFAs for adoption of Web 2.0 tools using DTBP model.

The three-factored latent construct and factor loads founded with first order CFA for adoption of Web 2.0 tools using DTBP model as the theoretical foundation (scale for the model are presented in Figure 2). Accordingly, INT1 (0.95) item under Behavioural Intention construct has the most impact on adoption of Web 2.0 tools, whereas Subjective norms (0.73) item under Subjective Norms has the least impact. Table 5 presents internal consistency (Cronbach's alpha) of the subscales as follows:

Table 5. Internal Consistency (Cronbach's Alpha) of the Subscales
\begin{tabular}{|l|c|c|}
\hline Subscales & Item No & $\boldsymbol{\alpha}$ \\
\hline Perceived Usefulness & 5 & .95 \\
\hline Subjective Norms & 5 & .92 \\
\hline Behavioural Intention & 3 & .94 \\
\hline Total Instrument & 13 & .94 \\
\hline
\end{tabular}


Çukurova Üniversitesi Sosyal Bilimler Enstitüsü Dergisi, Cilt 30, Sayı 3, 2021, Sayfa 235-250

As given in Table 5., Cronbach's alpha values are .94 for the whole subscales, Perceived Usefulness $=.95$; Subjective Norms $=.92$; Behavioural Intention $=.94$. A large and growing body of literature suggest that scales with reliability coefficients of .70 and above is reliable.

\section{Semi-Structured Interview}

A pilot study with three volunteer participants and member-checking procedures were employed to seek objective opinions as to how semi-structured interview questions could be made easier to understand, avoid bias or leading questions and/or avoid any potential ambiguity, and employ a valid and reliable qualitative data procedure. After member-checking, minor phrasing revisions were incorporated into the final version of the semi-structured interview utilized in the present study.

In qualitative research, reliability refers to the repeatability of the research results obtained. External reliability is related to whether the results of the research can be obtained in the same way in similar settings, and internal reliability is associated with whether other researchers can achieve the same results using the same data set (LeCompte and Goetz, 1982).

Internal reliability of the qualitative data includes the following steps. First, the researcher has stated his position who merely conducted the interview and analysed the data. Second, the variables regarding the participants in the research are clearly indicated. Third, data collection and data analysis procedure are explained in detail. Fourth, in order to maintain internal reliability, the direct quotations from the semi-structured interview is given without any objective changes. Giving direct quotations can increase the validity and reliability of qualitative data (Neuman, 2013). Finally, while analysing data, the theoretical framework based on the previous studies related to current research and other research findings was compared.

\section{Data Collection Procedure}

Data collection process commenced during the spring semester of 2018 and 2019 academic years. Prior to gathering data, permission to use the instruments was obtained from the developers and researchers. Next, the Provincial Directorate for National Education, Diyarbakır-Turkey was contacted to obtain permission to gather data from the volunteer EFL teachers who work in public schools in Bağlar, Sur, Kayapınar, and Yenişehir districts of Diyarbakır-Turkey. Then a pilot study was carried out two weeks ahead of the main study. As for the main data collection, the schools were randomly selected to gather data from the volunteer participants. First, quantitative data was collected via survey questionnaire in the school settings of the 202 participants from 183 schools between March 1 and June 1 in 2019. Then, semi-structured interviews were conducted with 10 EFL teachers who work in different public schools in the academic year of 2018 and 2019. Before the semi-structured interview took place, all the participants were asked if they would like to take part in the study. Ten EFL teachers were volunteer to be visited in their schools and being audio recorded within a certain amount of time ranging from 25 minutes to 42 minutes.

\section{RESEARCH FINDINGS}

The present study aimed to investigate the relationship between the self-efficacy beliefs and attitudes of the EFL teachers towards the Web 2.0 tools in Turkey. The findings of quantitative data are displayed in the following tables.

Table 6. Demographic Variables of the Respondents to the Questionnaire

\begin{tabular}{|l|l|l|l|}
\hline Variables & Properties & $\mathbf{N}$ & $\mathbf{\%}$ \\
\hline \multirow{4}{*}{ Gender } & Male & 88 & 43,6 \\
\cline { 2 - 4 } & Female & 114 & 56,4 \\
\cline { 2 - 4 } & Total & 202 & 100,0 \\
\hline \multirow{5}{*}{ Age Groups } & $21-24$ ages & 13 & 6,4 \\
\cline { 2 - 4 } & $25-29$ ages & 69 & 34,2 \\
\cline { 2 - 4 } & $30-34$ ages & 48 & 23,8 \\
\cline { 2 - 4 } & $35-39$ ages & 34 & 16,8 \\
\cline { 2 - 4 } & $40-44$ ages & 25 & 12,4 \\
\cline { 2 - 4 } & $45-49$ ages & 5 & 2,5 \\
\cline { 2 - 4 } & $50-54$ ages & 4 & 2,0 \\
\cline { 2 - 4 } & 55 and over & 4 & 2,0 \\
\cline { 2 - 4 } & Total & 202 & 100,0 \\
\hline \multirow{5}{*}{ Teaching Experience } & $0-5$ years & 75 & 37,1 \\
\cline { 2 - 4 } & $6-10$ years & 47 & 23,3 \\
\cline { 2 - 3 } & $11-15$ years & 40 & 19,8 \\
\hline
\end{tabular}


Çukurova Üniversitesi Sosyal Bilimler Enstitüsü Dergisi, Cilt 30, Sayı 3, 2021, Sayfa 235-250

\begin{tabular}{|c|c|c|c|}
\hline & $16-20$ years & 28 & 13,9 \\
\hline & 21 and above & 12 & 5,9 \\
\hline & Total & 202 & 100,0 \\
\hline \multirow{3}{*}{ Education degree } & Graduate & 182 & 90,1 \\
\hline & Postgraduate & 20 & 9,9 \\
\hline & Total & 202 & 100,0 \\
\hline \multirow{4}{*}{ Level of school } & Primary School & 60 & 29,7 \\
\hline & Secondary School & 83 & 41,1 \\
\hline & High School & 59 & 29,2 \\
\hline & Total & 202 & 100,0 \\
\hline \multirow{5}{*}{ District of the school } & Bağlar & 62 & 30,7 \\
\hline & Kayapınar & 55 & 27,2 \\
\hline & Sur & 42 & 20,8 \\
\hline & Yenişehir & 43 & 21,3 \\
\hline & Total & 202 & 100,0 \\
\hline
\end{tabular}

As accentuated in Table 8, the total number of the participants who responded to the questionnaires was $56.4 \%$ identified as female and $43.6 \%$ reported as male. The highest percentage (34.2\%) of the age group of the participants is observed between $25-29$ years old, whereas the lowest percentage $(2.5 \%)$ is between 50 and over. The teaching experiences of the participants were $0-5$ years $(37,1 \%), 6-10$ years $(23,3 \%), 11-15$ years $(19,8 \%)$, $16-20$ years $(13,9 \%), 21$ and above $(5,9 \%)$. According to the degrees they held, a bachelor degree, $9,1 \%$ of them reported to have an MA or a $\mathrm{PhD}$ degree. $29,7 \%$ of the participants worked in primary schools, $41,1 \%$ in secondary schools, and $29,2 \%$ in high schools. Finally, as given in Table $8,30,7 \%$ of the respondents reported that they worked in Bağlar district, 27,2\% in Kayapınar, 20,8\% in Sur and 21,3\% in Yenişehir.

Table 7. Mean Scores and Standard Deviations of Decomposed Theory of Planned Behaviour (DTPB)

\begin{tabular}{|l|c|c|}
\hline Constructs & Mean & Std. Deviation \\
\hline Actual usage/behaviour & 3,70 & 0,82 \\
\hline Behavioural intention & 3,51 & 0,94 \\
\hline Attitude & 3,88 & 0,89 \\
\hline Ease of use & 3,63 & 0,85 \\
\hline Perceived usefulness & 3,90 & 0,85 \\
\hline Subjective norms & 3,40 & 0,96 \\
\hline Perceived behavioural control & 3,45 & 0,88 \\
\hline Peer influence & 3,49 & 0,93 \\
\hline Superior influence & 3,54 & 0,91 \\
\hline Student influence & 3,63 & 0,90 \\
\hline Compatibility & 3,72 & 1,01 \\
\hline Facilitating conditions & 3,53 & 0,86 \\
\hline Self-efficacy & 3,50 & \\
\hline Valid N (listwise) & & \\
\hline
\end{tabular}

The results given in Table 7 confirm the attitudes towards adopting Web 2.0 technologies. Items focused on areas ranging from the highest as perceived usefulness $(m=3,90)$, attitude $(m=3,88)$, compatibility $(m=3,72)$ to the lowest as perceived behavioural control $(m=3,40)$ and subjective norms $(m=3,40)$. To these findings, teachers have positive attitudes towards using Web 2.0 technologies in learning process.

The Pearson product moment correlation coefficient was conducted in order to assess the relationship between EFL teachers' self-efficacy level of Web 2.0 tools integration into their instructions and Web 2.0 adoption scores. In correlation tests, correlation forces are interpreted as a small relationship between .10 and .29 , moderate between .30 and .49, and high correlation between .50-1.00 (Cohen, 1988). Further, Cohen (1988) interprets that correlation coefficient between .10 and .29 is thought to represent a weak or small association; a correlation coefficient of .30 and .49 is considered a moderate correlation; and a correlation coefficient of .50 and 1.00 or larger is thought to represent a strong or large correlation. Table 8 indicates Pearson correlation between self-efficacy and attitudes of the EFL teachers towards Web 2.0 tools use. 
Çukurova Üniversitesi Sosyal Bilimler Enstitüsü Dergisi, Cilt 30, Sayı 3, 2021, Sayfa 235-250

Table 2. Pearson Correlation Between Self-Efficacy and Attitudes of the EFL Teachers Towards Web 2.0 Tools

\begin{tabular}{|c|c|c|c|c|c|c|c|c|c|c|}
\hline & Blogs & Wikis & Podcasts & SNSs & IPSs & CMSs & WTISE & $\mathbf{P U}$ & $\mathbf{S N}$ & BI \\
\hline Wikis & $.71^{* *}$ & & & & & & & & & \\
\hline Podcasts & $.62^{* *}$ & $.69^{* *}$ & & & & & & & & \\
\hline Social Networking Sites (SNSs) & $.55^{* *}$ & $.50^{* *}$ & $.58^{* *}$ & & & & & & & \\
\hline $\begin{array}{c}\text { Image/Photo Sharing Sites } \\
\text { (IPSs) }\end{array}$ & $.49^{* *}$ & $.56^{* *}$ & $.59^{* *}$ & $.73^{* *}$ & & & & & & \\
\hline $\begin{array}{c}\text { Course Management Systems } \\
(\mathrm{CMSs})\end{array}$ & $.60^{* *}$ & $.56^{* *}$ & $.62^{* *}$ & $.56^{* *}$ & $.62^{* *}$ & & & & & \\
\hline WTISE & $.83^{* *}$ & $.84^{* *}$ & $.83^{* *}$ & $.80^{* *}$ & $.80^{* *}$ & $.80^{* *}$ & & & & \\
\hline Perceived usefulness PU) & $.34^{* *}$ & $.37^{* *}$ & $.35^{* *}$ & $.43^{* *}$ & $.43^{* *}$ & $.45^{* *}$ & $.48^{* *}$ & & & \\
\hline Subjective norms (SN) & $.35^{* *}$ & $.40^{* *}$ & $.39^{* *}$ & $.29^{* * *}$ & $.34^{* *}$ & $.46^{* * *}$ & $.45^{* *}$ & $.61^{* *}$ & & \\
\hline Behavioural Intention (BI) & $.48^{* * *}$ & $.38^{* *}$ & $.42^{* *}$ & $.51^{* * *}$ & $.46^{* *}$ & $.49^{* *}$ & $.56^{* *}$ & $.59^{* *}$ & $.57^{* * *}$ & \\
\hline DTPB & $.44^{* *}$ & $.45^{* *}$ & $.45^{* *}$ & $.47^{* *}$ & $.47^{* *}$ & $.54^{* *}$ & $.57^{* *}$ & $.88^{* *}$ & $.87^{* *}$ & $.80^{* *}$ \\
\hline
\end{tabular}

The results of the correlational analysis examined in Table 8 indicate that there is a positive and significant relationship between the EFL teachers' Web 2.0 tools self-efficacy and attitudes towards the Web 2.0 tool adoption $(\mathrm{r}=.57 ; \mathrm{p}<.001)$. When the relationships with the WTSIE constructs and the DTPB model to measure attitudes towards the Web 2.0 tool adoption are examined, the results reveal that there is a positive and moderate level of relationship $(\mathrm{p}<.001)$. When the relationship between DTPB constructs and WTSIE constructs are analysed, the results demonstrate positive, high-strength significant relationship with Behavioural Intention, while the other constructs including Subjective Norms and Perceived Usefulness show a positive and mediumsignificant relationship. Thus, it can be said that there is a relationship between self-efficacy and attitudes of the EFL teachers towards the Web 2.0 tools.

\section{EFL Teachers' Self-Efficacy Beliefs Towards Web 2.0 Tools}

Whether or not participants' self-efficacy beliefs towards Web 2.0 tools caused any significant differences in the scale for determining EFL teachers' use of Web 2.0 was checked through open-ended questions that ask their level of comfort. The opinions on these statements were as in following:

P3. "The syllabus can also be adapted to the Web 2.0 tools by MoNE. I would definitely need more trainings."

P7. "More trainings can be helpful to get confident in using Web 2.0 tools for my lessons and curriculum would be more suitable for using them.",

P8. "I will be comfortable 100\% if any Web 2.0 tools is recommended by MoNE. I can't be sure about these tools' credibility and that is why I can't recommend my students to use them."

Few of those interviewed suggested technology infrastructure be improved to increase her self-efficacy level as given below:

P9. "If my school is equipped with devices such as smartboard, computer classes and students with a tablet device, then I would be confident."

\section{EFL Teachers' Attitudes Towards Web 2.0 Tools}

Open-ended questions were asked during the interview in an attempt to reveal the participants' opinions about their attitudes towards Web 2.0 tools in regards to its role in education as an instructional tool and feelings about using them in their classrooms.

All participants reported that ease of use of use and perceived usefulness were the most significant factors affecting their intentions to use Web 2.0 tools. The participants indicated that social factors exert a positive influence on intentions to use Web 2.0 tools. Some of the statements of such opinions were in the following:
P1. "Web 2.0 tools play crucial role in $21^{\text {st }}$ century education system, especially, when we are all surrounded with technological devices. Web 2.0 tools are amusing and innovations that help me teach English."
P2. “Web 2.0 tools foster students' learning and make teachers' job easier to give innovative lessons. They 
Çukurova Üniversitesi Sosyal Bilimler Enstitüsü Dergisi, Cilt 30, Sayı 3, 2021, Sayfa 235-250

provide massive teaching source for education. They are available at any time, at any place."

P4. "Technology is a must for the 21st century's education system. They are free and effective to facilitate teaching and learning. They provide valuable teaching source for education."

P5. "Web 2.0 tools offer many benefits. It enables collaboration and corporation anywhere and anytime. Web 2.0 tools are good idea and they are helpful sources."

P6. "They have a lot of important advantages in terms of time and effectiveness. They are more entertaining than books and notebooks for children. They are easy, fun and engaging tools you can use anytime and anywhere."

P7. "It has an important role to get students used to the autonomous learning through technology, which is the future of the education system. Using Web 2.0 tools motivate me to use technology in my lessons."

P8. "They are quite important because of the changing circumstances and standards. We should notice that they are only "tools", which means we can do our job with or without them. They should not be the "aim" of education. I am not biased, but I don't make my lesson plans by relying on them."

P9. "It is really necessary to incorporate Web 2.0 tools into today's English classrooms. They are great tools to teach language skills such as reading, listening, writing and speaking. I think they are easy and dynamic tools to use for teaching English."

P10. "Web 2.0 tools are so important in teaching languages. A learner can study autonomously and collaborate with their classroom friends. They can use it anywhere and anytime. Web 2.0 tools provide enriched content."

As afore-mentioned, the results reported that teachers' self-efficacy is a significant predictor of behavioural intention to use Web 2.0 tools. Likewise, subjective norms and perceived usefulness put forward a positive and medium-significant relationship. Thus, it can be concluded that the ease of use and perceived usefulness can predict the EFL teachers' intentions to use Web 2.0 tools in their future classrooms.

The current study also indicated a positive attitude towards the use of social networking sites only, which can be interpreted that teachers who had positive attitudes towards social networking sites used them more often than the other Web 2.0 tools. Although teachers had positive attitudes towards Web 2.0 tools in general, they did not use them as often as social networking sites. The qualitative findings revealed the participants' opinions about their attitudes towards Web 2.0 tools in regards to its role in education as an instructional tool and feelings about using them in their classrooms. All participants reported that ease of use and perceived usefulness were the most significant factors affecting their intentions to use Web 2.0 tools. That is to say, the EFL teachers stated that Web 2.0 tools provide amusing, easy, helpful, innovative, effective, valuable, collaborative, cooperative, time-saving, engaging, autonomous, motivating, fostering, and facilitating learning.

\section{CONCLUSION}

Based on the findings of the present study, EFL teachers mostly used social networking sites and blogs, followed by wikis, podcasts and image/photo sharing sites. The least frequently used tools were course management systems. The popularity of social networks, blogs, and image/photo sharing sites in their daily life may have led these tools to be frequently used by EFL teachers. However, it can be inferred that the majority of teachers rarely incorporated course management systems into their lessons since they may not need these tools in their daily lives. Semi-structured interview results indicated that lack of time and lack of technology infrastructure negatively affect teachers' Web 2.0 tools use during a regular school day. From this aspect, teachers should be given more time and up-to-date infrastructure to promote their use of Web 2.0 tools.

EFL teachers' self-efficacy level did not differ according to their demographic variables such as gender, teaching experience, teachers' experience level, in-service training background, experience in using a device to connect to the Internet. Previous research also corroborates the results of the present study. However, teachers' age affected their self-efficacy levels towards the use of podcasts and social networking sites. Previous research concluded that age does not correlate with self-efficacy because individuals vary greatly in how efficacious they manage their lives. Results of the current study indicated that teachers between 21 and 24 ages had higher selfefficacy than those who are at the age of 40 and above. It may be due to the fact that the initial is amongst the generation $\mathrm{Z}$ and they are quite intertwined with technology, thus their self-efficacy level is the highest. Teachers also reported that their self-efficacy levels were influenced by insufficient infrastructure and insufficient inservice teacher training, which prevented an effective adoption of Web 2.0 tools. With this regard, MoNE should provide teachers who are 40 and above with more the in-service teacher trainings in an effort to increase 
Çukurova Üniversitesi Sosyal Bilimler Enstitüsü Dergisi, Cilt 30, Sayı 3, 2021, Sayfa 235-250

teachers' self-efficacy towards Web 2.0 tools. The results were broadly in line with Alhassan's (2017) and DoBell's (2013) findings as one of the most significant factors influences teachers' use of Web 2.0 tools in their teaching was their in-service training to use these tools. Similar conclusions reported that the in-service teacher training is one of the most significant agents influencing whether school teachers use and incorporate classroom technology (Niederhauser \& Perkmen, 2008; Pan, 2010; Ross \& Bruce, 2007; Wang \& Newby, 2004).

In a general sense, EFL teachers indicated positive attitudes towards using Web 2.0 technologies in learning process. They reported that using Web 2.0 tools is a good idea, helps their students learn more about the subject, and improves students' satisfaction with the course. These results tie well with previous studies wherein most teachers had positive attitudes towards the use of Web 2.0 tools in general. In contrast to previous results, teachers' gender, age, teaching experience, school levels, and net connection years did not affect the attitudes of them towards Web 2.0 tools. Although teachers had positive attitudes towards Web 2.0 tools, they reported that the Internet connection problem, intensive curriculum, crowded classrooms, inadequate servers, technical problems and negative attitudes of administrators may cause them to adopt negative attitudes towards Web 2.0 tools. These results are in accord with previous studies indicating that though EFL instructors showed a positive attitude towards the use of the Internet and Web 2.0 tools in language teaching, they were not using these tools adequately in their teaching (Özel \& Arıkan, 2015). There are similar attitudes expressed by Onbasili (2020) describing that the participants found Web 2.0 tools easy, convenient and enjoyable to use and that they wanted to use those tools in other courses. The findings of this study also support the evidence from previous observations of Ünlüer (2018) reported that the use of Web 2.0 tools in lessons taught by prospective teachers made the lessons more enjoyable, provided fun learning, attracted students' attention, and students participated in lessons more. Therefore, it provided retention in learning, autonomy, and easier learning process.

During the interviews, EFL teachers stated that Web 2.0 tools provide valuable, collaborative, cooperative, effective learning in addition to amusing, easy, helpful, innovative, timesaving, engaging, autonomous, motivating, fostering and facilitating learning.. However, teachers only had positive attitudes towards the use of social networking sites. Popularity of social networking sites can lead teachers to develop positive attitudes towards the incorporation of Web 2.0 tools into their lessons if they were given chances like decreasing their burdens such as overloading schedules and integration of technology more than ever not merely in their school settings but also in the other environments they could utilize these tools free.

EFL teachers' perceived usefulness and subjective norms can predict the EFL teachers' intentions to use Web 2.0 tools in their future classrooms. These results match those observed in earlier studies where pre-service teachers' positive attitudes of perceived usefulness of Web 2.0 tools were the strongest determinant of their intentions (Khati, 2016; Sadaf, Newby \& Ertmer, 2016; 2012). The body of literature indicated that the perceived usefulness and ease of use positively affect technology acceptance of teachers (Cakar; 2018; Lee \& Coughlin, 2015; Usluel \& Mazman, 2010), and their intention to use technology (Jeung, 2014).

\section{REFERENCES}

Abbitt, J. (2011). An investigation of the relationship between self-efficacy beliefs about technology integration and technological pedagogical content knowledge (TPACK) among preservice teachers. Journal of Digital Learning in Teacher Education, 27(4), 134-143.

Ajjan, H. \& Hartshorne, R. (2008). Investigating faculty decisions to adopt Web 2.0 technologies: Theory and empirical tests. The Internet and Higher Education, 11(2), 71-80.

Bandura, A. (1995). Self-efficacy in changing societies. Cambridge University Press.

Batsila, M., Vavougios, D., Tsihouridis, C. \& Ioannidis, GS (2014). Teachers' attitudes towards the use of Web 2.0 tools in educational practice - A critical approach. 2014 International Conference on Interactive Collaborative Learning (ICL). Presented at the 2014 International Conference on Interactive Collaborative Learning (ICL).

Brown, R. (2009). Public relations and the social web: How to use social media and Web 2.0 in communications. Kogan Page. 
Çukurova Üniversitesi Sosyal Bilimler Enstitüsü Dergisi, Cilt 30, Sayı 3, 2021, Sayfa 235-250

Chartland, R. (2012). Social networking for language learners: Creating meaningful output with Web 2.0 tools. Knowledge Management and E-learning: An International Journal, 4(1), 97-101.

Cohen, J. (1988). Statistical power analysis for the behavioural sciences (2nd Ed.). Erlbaum.

Cohen, L., Manion, L. \& Morrison, K. (2007). Research methods in education. Routledge.

Conole, G. \& Alevizou, P. (2010). A literature review of the use of Web 2.0 tools in Higher Education. HEA Academy.

Data Reportal. (2019). Digital in 2019: Turkey. https://datareportal.com/reports/digital-2019-turkey

Davies, J. \& Merchant, G. (2008). Web 2.0 for Schools: Learning and Social participation. Peter Lang Publishing.

Davis, F. (1989). Perceived usefulness, perceived ease of use, and user acceptance of information technology. MIS Quarterly, 13, 319-339.

Demirkan, O. (2019). Pre-service teachers' views about digital teaching materials. Educational Policy Analysis and Strategic Research, 14(1), 40-60.

Eagly, AH \& Chaiken, S. (1993). The psychology of attitudes. Fort Worth, Harcourt Brace Jovanovich.

Farah, AC (2011). Factors influencing teachers' technology self-efficacy: A case study. Published Doctoral Dissertation, Liberty University.

Field, AP (2009). Discovering statistics using SPSS (3rd Ed.). Sage publications.

Fishbein, M. \& Ajzen, I. (1975). Belief, Attitude, Intention, and Behaviour: An Introduction to Theory and Research. Addison-Wesley.

Fraenkel, JR, Wallen, NE \& Hyun, HH (2012). How to design and evaluate research in education (8th Ed.). McGraw Hill.

Gabriel, MA \& Macdonald, CJ (1996). "Preservice teacher education students and computers: how does intervention affect attitudes?", Journal of Technology and Teacher Education, 4(2), 91-116.

Haydn, TA \& Barton, R. (2007). Common need sand different agendas: How trainee teachers make progress in their ability to use ICT in subject teaching. Some lessons from the UK. Computers and Education, 49(4), 1018-1036.

Horzum, MB (2007). Web tabanlı yeni öğretim teknolojileri: Web 2.0 araçları [New Web-based teaching technologies: Web 2.0 tools]. Journal of Educational Sciences \& Practices, 6(12), 99-121.

Horzum, MB (2011). Adaptation of Web pedagogical content knowledge survey to Turkish. Elementary Education Online, 10(1), 257-272.

Kia Heirati, J. \& Ahmadi Alashti, L. (2015). Attitudes toward using the Internet for language learning: A case of Iranian English teachers and learners. International Journal of Research Studies in Educational Technology, 4(1).

Kostoula-Christina, K. (2016). Teachers' attitudes towards the integration of Web 2.0 tools in EFL teaching. Research Papers in Language Teaching and Learning, 7(1), 46. 
Çukurova Üniversitesi Sosyal Bilimler Enstitüsü Dergisi, Cilt 30, Sayı 3, 2021, Sayfa 235-250

Kreijns, K., Acker, F., Vermeulen, M. \& Buuren, H. (2013). What stimulates teachers to integrate ICT in their pedagogical practices? The use of digital learning materials in education. Computers in Human Behaviour, 29(1), 217-225.

LeCompte, MD \& Goetz, JP (1982). Problems of reliability and validity in ethnographic research. Review of Educational Research, 52(1), 31-60.

Lemke, C., Coughlin, E., Garcia, L., Reifsneider, D. \& Baas, J. (2009). Leadership for Web 2.0 in education: Promise and reality. Metiri Group.

Lodico, M., Spaulding, D. \& Voegtle, K. (2010). Methods in educational research: from theory to practice. Jossey-Bass.

Ministry of National Education. (1997). Çă̆l Yakalama 2000 Projesi [Three-Year Catch 2000 Project]. MEB Araştırma, Planlama ve Koordinasyon Kurulu.

Ministry of National Education. (2011). the FATIH Project. http://fatihprojesi.meb.gov.tr/en/?page_id=10

Neuman, W. (2013). Social research methods: qualitative and quantitative approaches. Pearson.

O'Reilly, T. (2005). What is Web 2.0: design patterns and business models for the next generation of software? Communications \& Strategies, 65, 17-37.

Oblinger, D. \& Oblinger, J. (2005). Is it age or IT: First steps towards understanding the netgeneration. In D. Oblinger, \& J. Oblinger (Eds.), Educating the Net Generation (pp. 2.1-2.20). Educause.

Özel, AG \& Arikan, A. (2015). The use of the internet and Web 2.0 tools among EFL instructors. Mediterranean Journal of Humanities, 5(1), 313-313.

Pacis, D., Sytsma, C., Weegar, MA, Keough, P., Wheeler, D. \& Bustillos, T. (2012). Educational achievement and satisfaction through generations. International Journal of Business and Social Science, 21, 57-62.

Pan, SC \& Franklin, T. (2011). In-service teachers' self-efficacy, professional development, and Web 2.0 tools for integration. New Horizons in Education, 59(3), 28-40.

Prensky, M. (2001). Digital natives, digital immigrants: A new way to look at our kids and ourselves. On the Horizon, 9(5).

Rogers, EM (1983). Diffusion of innovations. Free Press.

Rubin, H. \& Rubin, I. (2012). Qualitative Interviewing: The Art of Hearing Data (3rd ed.). SAGE.

Schulmeister, R. (2008). Is There a Net Generation in the House? Dispelling a Mystification. eLeed. http://eleed.campussource.de

Smith, MB (1968). Attitude change. International encyclopaedia of the social sciences. Crewell Collier and Mac Millan.

Solomon, G. \& Schrum, L. (2007). Web 2.0: new tools, new schools. Eugene, Or: International Society for Technology in Education.

Thompson, J. (2007). Is education 1.0 ready for web 2.0 students?. Innovate: Journal of Online Education, 3(4), No: 5 . 
Çukurova Üniversitesi Sosyal Bilimler Enstitüsü Dergisi, Cilt 30, Sayı 3, 2021, Sayfa 235-250

Twenge, JM, Campbell, SM, Hoffman, BJ \& Lance, CE (2010). Generational differences in work values: Leisure and extrinsic values increasing, social and intrinsic values decreasing. Journal of Management, $36(5), 1117-1142$.

Ursavaş, ÖF, Şahin, S. \& McIlroy, D. (2014). Technology acceptance measure for teachers: T-TAM. Journal of Theory and Practice in Education, 10(4), 885-917.

Venkatesh, V., Morris, MG, Davis, GB \& Davis, FD (2003). User acceptance of information technology: toward a unified view. MIS Quarterly, 27(3), 425. https://doi.org/10.2307/30036540

\section{Yazar Katkı Oranı}

Birinci yazarın çalışmadaki katkı oranı $\% 60$, ikinci yazarın katkı oranı ise $\% 40$ 'tır. 